\title{
6 A literatura lésbica entre o virtual e o impresso
}

Ismênia de Oliveira Holanda *

Antonio Crístian Saraiva Paiva

* Professora e Socióloga. Mestre e Doutoranda em Sociologia pela

Universidade Federal do Ceará.

Resumo: Este artigo analisa a trajetória de Karina Dias, uma escritora assumidamente lésbica que publicava somente em blogs e sites voltados para a cultura lésbica e que hoje publica, também, em livros impressos. A internet é ponto chave neste artigo, pois se analisa a formação de escritoras brasileiras tendo como elemento propulsor de suas carreiras o advento de blogs e sites de divulgação de textos lésbicos. Objetivou-se, a partir da análise desta trajetória específica, compreender o processo de transição de escritores do mundo digital para o impresso, assim como a sua relação com estes dois tipos de publicação (virtual e física). Analisou-se a trajetória de vida desta escritora, buscando traçar pontos de continuidade e de descontinuidade na experiência de ser uma escritora pertencente a uma minoria sexual e que tem sua escrita voltada para este público.

Palavas-chave: Literatura Brasileira. Literatura Lésbica. Internet. Mercado Editorial. Formação de escritoras.

Abstract: This article analyzes the trajectory of Karina Dias, an openly lesbian writer who published only in blogs and facing sites lesbian culture and now also publishes books in print. The internet is a key point in this article, because it analyzes the formation of Brazilian writers with an impetus of their careers the advent of blogs and disclosure of lesbians texts sites. The objective of starting the examination of this particular trend understand the transition process of the digital world writers for printed, as well as their relationship with these two types of publication (virtual and physical). Analyzed the life story of this writer, seeking to trace points of continuity and discontinuity in the experience of being a writer belonging to a sexual minority and have your writing aimed at this audience.

Key-words: Brazilian Literature. Lesbian Literature. Internet. Publishing Market Writers' formation. 


\section{Ismênia de Oliveira Holanda}

Antonio Crístian Saraiva Paiva

\section{Introdução}

No presente artigo analiso a trajetória de Karina Dias, uma escritora assumidamente lésbica que antes publicava somente em blogs e sites voltados para a cultura lésbica e que hoje publica, também, em livros impressos. Esta escritora, além de assumir a sua homossexualidade, escreve textos voltados para lésbicas e cujas personagens principais também pertencem a essa minoria sexual.

Tenho por objetivo compreender, a partir da análise desta trajetória específica, o processo de transição de escritores do mundo digital para o impresso, assim como a sua relação com estes dois tipos de publicação (virtual e física), publicações estas que não podem mais ser separadas diante da importância da internet como forma de divulgação de novos escritores. Para tanto, realizei um estudo das obras desta escritora e, mais profundamente, analisei a trajetória de vida dela, buscando traçar pontos de continuidade e de descontinuidade na experiência de ser uma escritora pertencente a uma minoria sexual e que tem sua escrita voltada para este público, que não é homogêneo.

Busquei acessar formas de inteligibilidade social sobre sujeitos subalternos (SPIVAK, 2010), tendo como campo de estudos as interseções campo/figuração literária e trajetória da autora/experiência de vida. Penso que o estudo de textos literários e de histórias de vida (DEBERT, 2004) são formas de permitir ao cientista social adentrar no campo das interpretações sobre conflitos, experiências e trajetórias associados às realidades das minorias sexuais femininas.

Para pensar a relevância da literatura para os estudos da sociedade, sigo a linha de pensamento de Eliane Soares, em seu artigo Embora lidando com literatura, você está fazendo sociologia. Segundo a autora,

o argumento que procuro desenvolver não propõe uma equivalência entre literatura e conhecimento científico. Busca explorar novos caminhos em que a literatura seja encarada como uma epistemologia válida para a compreensão das dinâmicas sociais." (SOARES, 2014, p. 81)

Objetiva-se, assim, analisar a trajetória de uma autora brasileira que transita entre a escrita em blogs e em livros. Neste sentido, parto do pressuposto de que tanto a trajetória de vida desta escritora quanto seus livros demonstram algumas formas de vivenciar a experiência homossexual feminina na sociedade brasileira contemporânea.

A formação de espaços de socialização e de publicação de textos lésbicos na internet tem produzido a chance de leitoras tornarem-se autoras representativas das mulheres homossexuais. Pude perceber, a partir das entrevistas realizadas com a autora, que um processo íntimo (a escrita) tem se tornado um processo coletivo e político (a afirmação de identidades lésbicas), voltado para um público específico. Criam-se, assim, textos com características pedagógicas, de autoaceitação, no qual uma autora fala em nome do público, colocando questões relativas à moral, expressando dilemas e experiências e formalizando soluções possíveis.

Há atualmente uma rede de compartilhamento virtual, que é uma forma dessas mulheres quebrarem a hegemonia das culturas legítimas (LAHIRE, 2006) que (d)escrevem sobre o que é ser/estar (HEILBORN, 1996) lésbica na sociedade contemporânea. Assim, 


\section{Ismênia de Oliveira Holanda}

Antonio Crístian Saraiva Paiva

o meio virtual, através de sites e blogs lésbicos, constitui-se como um espaço de compartilhamento de experiências e vivências comuns, porém pautadas pela questão da diversidade de gênero e de orientação sexual.

\section{A escrita lésbica no Brasil}

Denise Portinari, no livro $O$ Discurso $d a$ Homossexualidade Feminina, afirma que o silêncio sobre personagens lésbicas está inserido em um contexto de ausência de obras que versem sobre o feminino como um todo, seja ele heterossexual ou homossexual. Entretanto, há um aprofundamento dos silêncios quanto à questão são personagens homossexuais femininas, afinal tais personagens pertencem a duas minorias sociais, por serem mulheres e por serem lésbicas, e estes grupos constituem-se também como minorias literárias.

Temos uma longa tradição literária masculina que não considera obras de escrita feminina e/ou voltadas para mulheres como sendo histórias sérias, partindo do pressuposto de que estas obras tratam de temas ditos "menores", assuntos relacionados ao amor e à vida doméstica, esferas elencadas pelo imaginário social como femininas.

Segundo Andrade (2011), a literatura homoerótica no Brasil surge a partir de pequenos traços, pistas, na obra $O$ Ateneu de Raul Pompéia, escrita em 1888. Depois desta obra, temos outras que nos dão indícios de relações homoafetivas, principalmente no período das escolas literárias do Realismo e do Naturalismo. Dentre estas, podemos destacar O Cortiço, de Aluísio de Azevedo, escrita em 1890 e que descreve uma série de tipos de relações sexuais das mais diversas, sendo, inclusive, a primeira obra brasileira a mostrar explicitamente uma relação homossexual feminina.

Andrade afirma, porém, que o real marco deste tipo de obra deu-se com a publicação, em 1895, do livro O Bom Criolo, de Adolfo Caminha. Este romance retrata a relação entre um grumete branco e um marinheiro negro, que sucumbe à paixão, mesmo sendo uma relação homossexual, interracial e em um ambiente militar.

Em termos de personagens lésbicas, Gregório de Matos escreveu alguns poemas sobre as lésbicas da Bahia no século XVII. Já no século XVIII, Joaquim Manuel de Macedo publicou As Mulheres de Mantilha, no qual duas mulheres se apaixonam, porém no final se descobre que uma delas era, na verdade, um homem travestido para fugir do serviço militar (LIMA, 2009). Mesmo com a publicação de Usina, José Lins do Rego, em 1936, o qual nos mostra o relacionamento entre uma dona de prostíbulo e uma prostituta, a primeira obra centrada e que mostra explicitamente um romance sexual e afetivo entre mulheres é a obra A Volúpia do Pecado, de Cassandra Rios, escrita em 1948.

Porém, mesmo com essa primeira aparição de um romance com um casal lésbico como personagens principais, isso não se configurou uma nova ordem. O que se pode perceber é que nos textos literários posteriores nos quais temos personagens lésbicas, em sua maioria elas não são as protagonistas. Neste sentido, há vestígios da representação de lésbicas em obras como nas obras Ciranda de pedra (1954), As Meninas (1973) e A Escolha (1985), de Lygia Fagundes Telles. 


\section{Ismênia de Oliveira Holanda}

\section{Antonio Crístian Saraiva Paiva}

Questões relativas às mulheres e protagonistas femininas foram apresentadas nas obras de autoras de destaque no Brasil na segunda metade do século XX, como Rachel de Queiroz, Lygia Fagundes Telles, Cassandra Rios e Clarice Lispector. Ainda que todas estas autoras fugissem do padrão feminino de mulher/esposa, por não terem filhos e/ou terem se separado, Cassandra Rios foi a única que, além disso, era homossexual assumida.

É importante lembrar que o Brasil deste período vivia sob a égide de uma ditadura civil-militar e que

\begin{abstract}
A partir dos anos 1960 , o bonito era a diferença. A ideia de igualdade universal era aos poucos substituída pela valorização da diferença, fosse ela de raça, faixa etária ou sexo. Efervesciam movimentos negros, feministas, homossexuais e até de universos menores, como as associações de bairro, que naquela ocasião ganhavam grande visibilidade (BURNS, 2009, p. 20)
\end{abstract}

Porém, mesmo com esta valorização da diversidade, ainda havia dificuldades para o movimento homossexual se firmar e as obras literárias de Cassandra Rios não eram vistas como parte deste movimento de afirmação identitária homossexual. A autora escreveu em um período em que os direitos da população LGBT ainda não estavam na pauta dos movimentos sociais brasileiros, que se centravam na busca por um direito básico: a liberdade ante a ditadura (MORALES, 2010).

Lésbica assumida, solteira e provocadora, Rios não parecia ser a pessoa que teria obras amplamente lidas no Brasil daquele tempo, mas foi o que ocorreu. Ela passou por um processo de estigmatização (GOFFMAN, 1988) de sua legitimidade nos campos social e literário. Seu nome era motivo de censura certa e, em alguns casos, prévia. Por isso usou pseudônimos masculinos e estrangeiros; e com este artifício fez uma brincadeira com os censores, pois os pseudônimos eram a tradução de seu sobrenome, como Rivers e Rivier. Muito lida na época da ditadura, Rios foi perseguida, censurada e hoje é praticamente esquecida.

As censuras aplicadas aos livros de Rios foram todas baseadas na moral e nos bons costumes, o que lhe rendeu apelidos como "A grande pornógrafa", "A safo de Perdizes", "Papisa da homossexualidade". Segundo Santos, "a linguagem e a literatura de Cassandra Rios têm valor cultural e histórico de resistência, pois documentam histórias apagadas pelo sistema de repressão e censura da ditadura militar, e contestam o sistema hegemônico da heterossexualidade compulsória" (SANTOS, 2005, p. 180). Já Facco e Lima afirmam que os textos foram "escritos sob os tacões homofóbicos da rígida censura militar, do desprezo da militância de esquerda e da repressão da sociedade patriarcal brasileira" (FACCO, LIMA, 2004, p. 2).

Em paralelo à produção literária de Cassandra Rios, havia também a produção de periódicos voltados para o público LGBT. Em sua maioria, tais revistas e jornais eram voltados para o público masculino, porém houve publicações destinadas ao público feminino, como a revista Chana com Chana, o jornal Xerereca e o fanzine Um outro olhar. Porém, tanto as publicações masculinas quanto as femininas sofriam dificuldades para serem vendidas em bancas e principalmente para obterem recursos oriundos de publicidade, o que dificultava que estas revistas tivessem um grande período de existência. Esta situação permanece até hoje e segundo Péret, “a instável trajetória das 


\section{Ismênia de Oliveira Holanda}

Antonio Crístian Saraiva Paiva

publicações voltadas para o público gay mostra que, em termos financeiros, elas ainda sofrem com o preconceito de anunciantes" (PÉRET, 2012, p. 95).

Segundo Dalcastagnè (2005), a literatura brasileira é marcada pela escrita masculina, branca e de classe média, tendo como personagens centrais homens de idade adulta e heterossexuais. Além do mais, estes livros são predominantemente publicados no eixo Rio-São Paulo e por editoras de grande porte. Assim sendo, pode-se afirmar que estas escritoras lésbicas são um grupo minoritário no campo literário, entretanto, assim como outros grupos, elas produzem seus próprios sentidos, suas literaturas.

Entender os sentidos fornecidos por estes grupos marginalizados é uma forma de compreensão da vivência e das relações do outro numa sociedade fortemente marcada por uma ideologia centrada na figura do homem, branco e heterossexual. Tal ideologia, como nos mostra Sousa Filho (2007), é um discurso acerca da realidade que tenta colocar como natural ou divino algo que foi construído culturalmente.

Navarro-Swain, reafirmando esta construção cultural, expõe que para o imaginário hegemônico ocidental o lesbianismo é afirmado como um desvio cuja simples existência:

abre brechas no bloco monolítico da heterossexualidade, protegido ferozmente por mulheres e homens generizados, pois assegura seu lugar na partilha do mundo. Na ordem do discurso, ser "mulher" com toda a assimetria que implica esta denominação, ou "mulher negra", "mulher latina" ou "mulher imigrante" é considerado ainda melhor que ser lésbica. (NAVARRO-SWAIN, 2002, p. 8)
Assim, a autora nos mostra o local de exclusão das lésbicas, visto que, dentre todos os grupos de mulheres excluídas, as lésbicas são a parcela de mulheres mais excluídas, exatamente pelo seu poder de unir-se a outra mulher e negar o modelo heterossexual dominado pela figura do falo.

Diante do exposto, não é de se espantar com o pequeno número de escritoras lésbicas e que se mostrem enquanto tal, escrevendo obras que fujam da representação de personagens principais homens, heterossexuais e brancos. Percebe-se a necessidade de destruir este modelo de personagens da literatura para construir novos personagens, novas ideias (COSTA, 1994).

Regina Dalcastagnè afirma que "o silêncio dos marginalizados é coberto por vozes que se sobrepõem a ele, vozes que buscam falar em nome deles, mas também, por vezes, é quebrado pela produção literária de seus próprios integrantes" (DALCASTAGNÈ, 2002, p. 34). Já Débora Ferreira (2004) mostra que há uma relação entre a ascensão da identidade feminina e a literatura como forma de resistência, pois a literatura auxiliaria na instauração de uma nova ordem onde as mulheres possam ser reconhecidas.

Ferreira (2004) afirma que é necessário produzir uma nova história, uma história feminina, tendo como protagonistas mulheres como outras quaisquer. De maneira semelhante, reafirmo a necessidade de se produzir histórias com protagonistas lésbicas, representando estas de uma forma tranquila e sem tantos tabus. A pluralidade de perspectivas sociais nas quais os autores e autoras de livros estão inseridos claramente reflete em suas produções, pois 
a forma diferenciada pela qual cada autor se sensibiliza e se comporta diante de um mesmo cenário, glosando um mesmo tema, testemunha uma mudança profunda de quadros mentais trazida em linguagem literária.”(SEVCENKO, 1983, p. 241).

Ocorre que esta mudança nos quadros mentais (e literários, especificamente) em relação às lésbicas tem ocorrido de forma lenta. Mesmo com o surgimento de personagens homossexuais em livros de consagradas escritoras brasileiras e mesmo com a vasta obra de Cassandra Rios, somente em 1999 foi publicado no Brasil um romance com protagonistas lésbicas no qual havia um final feliz. Trata-se da obra Julieta e Julieta, da jornalista Fátima Mesquita, publicado pelo selo Edições GLS, que hoje em dia não mais existe.

Entre agosto de 2008 e janeiro de 2015 funcionou em São Paulo uma editora voltada para publicações a escritas por lésbicas e com protagonistas lésbica, trata-se da Editora Brejeira Malagueta, fundada pelo casal Hanna Korich e Laura Bacellar. Ambas já participavam de movimentos homossexuais e de espaços de fomento da homocultura, como saraus e eventos. Bacellar, mais especificamente, já trabalhava como editora de textos e vinha voltando o seu trabalho para obras que abordassem as questões das homossexualidades. Porém, ao perceber a necessidade de fortalecimento da rede de leituras de textos lésbicos, o que Lahire (2006) denominara como uma rede de culturas não-legítimas, ela resolveu focar o seu trabalho naquele público que mais conhecia: as lésbicas.

Mesmo com a existência de selos editoriais para o público LGBT, como o já citado Edições GLS, o que se percebeu era que os mesmos centravam suas publicações para o público gay, tendo bem menos títulos voltadas para o público lésbico ou trans (HOLANDA, 2012). Segundo no mostra Facco (2003), há uma lacuna no tocante a representação de ideias positivas e finais felizes para personagens lésbicas na literatura brasileira. Pode-se perceber que, em nossa literatura, há uma sub-representação destas mulheres e quando são representadas o são com características estereotipadas (masculinidade, violência, uso de drogas) e com um final semelhante: trágico e solitário

Em seu processo de divulgação, a editora Malagueta mostrou sofrer, além de preconceito homofóbico, os mesmo problemas que diversas outras editoras de pequeno porte ou de nicho sofrem: dificuldade para que seus livros sejam vendidos em grandes livrarias e que estejam em vitrines de destaque. Cabe ressaltar que muitas vezes tais posições de destaque dentro de uma livraria não são aleatórias, mas sim fruto de negociações e pagamentos por espaços, o que dificulta a visibilidade de grupos que não estejam dentro dos grandes circuitos de editoras e livrarias.

Diante disso, editoras de pequeno porte têm criado novas estratégias de marketing, em geral mais baratas. Essa questão faz da internet um forte aliado na consolidação da relação com o público-alvo, pois é ela o meio de divulgação que mais fortemente a editora tem utilizado para transpor as barreiras citadas.

Além do uso da internet, através de seu site e página no Facebook, a Editora realizava eventos próprios, como saraus, com leituras de textos lésbicos da própria editora e de outras autoras, e a produção e apresentação de um programa quinzenal chamado $A s$ Brejeiras. Neste programa, disponibilizado no site Youtube, as donas da editora conversavam com entrevistados sobre temas 


\section{Ismênia de Oliveira Holanda}

Antonio Crístian Saraiva Paiva

relacionados ao universo lésbico e sobre questões que fossem importantes no momento. Além disso, elas levavam as autoras dos livros publicados para conversarem sobre os mesmos e lerem trechos selecionados.

Percebe-se que estes eventos, assim como o programa, não têm somente o intuito de vender os livros da editora, mas de fortalecer uma cultura de grupo em torno das mulheres lésbicas. Trata-se da junção de várias expressões artísticas, não somente a literatura, envolvendo as realidades de mulheres homossexuais (HOLANDA, 2012)

A Brejeira Malagueta criou oportunidades de publicação para aquelas escritoras que, em geral, não conseguiam publicar suas obras em editoras de grande porte e que por isso disponibilizavam seus textos para download gratuito na internet. Porém, por mais que tenha ocorrido a existência de uma editora que publique estes livros, há toda a lógica do mercado editorial brasileiro que é contrária à existência de pequenas editoras que publiquem livros fora dos moldes hegemônicos.

Cíntia Schwantes (2000), ao falar sobre a importância de livros escritos por mulheres, afirma que "livros nascem de outros livros", daí a necessidade de obras voltados à representação do feminino para criar e fortalecer as culturas dos grupos diversos de mulheres, sejam elas heterossexuais ou homossexuais. A editora e as autoras colocam-se, então, como uma espécie de "profissionais da representação", que fazem do estigma a elas atribuído (ser lésbica) uma forma de empoderamento, tornando-as capazes de representar o grupo do qual fazem parte (GOFFMAN, 2007).

Neste artigo, porém, mais importante do que pensar a editora é compreender as modificações que ela trouxe para aquelas mulheres que acessavam tais textos somente pela internet. $\mathrm{O}$ meio eletrônico atenua a diferença hierárquica entre o autor e o leitor, entre produção e consumo, transformando o leitor em um autor em potencial, que pode disponibilizar seus textos na biblioteca virtual (BELLEI, 2002). É a partir desta percepção que Bellei fala da existência do leitor que simultaneamente lê e escreve o texto, o wreader, oriundo da junção do writer (escritor), com o reader (leitor).

Com o surgimento da figura do wreader, e a quebra da hierarquia entre leitor e escritor que a internet propiciou, pode-se perceber que esses textos com protagonistas lésbicas buscam abordar assuntos da vida cotidiana sob a perspectiva de quem está à margem da sociedade por não pertencer à maioria de orientação heterossexual, mas que nem por isso merece menos respeito ou validação. Nesses textos as wreaders passam a expor sobre a realidade e as identidades lésbicas não somente para as lésbicas, mas também para a sociedade como um todo, na medida em que tais textos ganham projeção no meio virtual. Assim, as diversas maneiras de vivenciar a homossexualidade feminina passam a ser expostas, contrastando com o único modelo e excludente da lésbica masculinizada tão comum em representações cotidianas. Não se busca, por outro lado, provar que não existem lésbicas masculinizadas, mas sim que esta é apenas uma das maneiras de expressão da identidade homossexual feminina (FACCHINI, 2009).

A experiência de publicação de textos na internet de forma coletiva não é uma experiência exclusiva de segmentos homossexuais, mas sim de grupos minoritários em geral e de segmentos de jovens envolvidos em culturas urbanas (LINHARES 


\section{Ismênia de Oliveira Holanda}

\section{Antonio Crístian Saraiva Paiva}

NETO, 2009; MUNIZ, 2010). Ocorre, porem, que os autores que não publicavam textos sobre minorias em geral fizeram mais rapidamente este processo de transição do texto virtual para os livros.

No Brasil, temos como caso expoente o dos escritores do fanzine virtual, ou mailzine, CardosoOnLine (COL), que fez um grande sucesso em grupos de jovens universitários entre os anos de 1998 e 2001 (LINHARES NETO, 2009). Já em 2001, ou seja, quando ainda existia este fanzine virtual, Daniel Galera passou a publicar em livros e em 2002 foi a vez de Clarah Averbuck, que além de publicar livros passou também a escrever em colunas de jornais e revistas.

O que se pode perceber, no caso de Galera e Averbuck, é que, tão logo seus textos gratuitos e virtuais passaram a repercutir também fora do meio virtual, eles foram rapidamente atraídos para o mercado editorial formal, impresso. Já no caso de escritoras que publicam textos voltados para lésbicas, mesmo havendo uma repercussão acerca dos seus textos, tal fato ficava circunscrito aos espaços de socialização de minorias sexuais

Somente com o advento de pequenos selos editoriais no final dos anos de 1990, e, mais fortemente, com o surgimento da Editora Brejeira Malagueta em 2008, foi que estes textos passaram a chamar a atenção de um pequeno grupo de editores. Com o advento da editora, passou a existir a possibilidade de profissionalização delas como escritoras, assim como já havia ocorrido com outros autores de textos virtuais.

\section{Escrever e se soltar}

Para entender o impacto do surgimento da editora para tais escritoras, estudei a trajetória de vida de Karina Dias. Penso que a trajetória de vida dessa autora dá suporte para entender o momento e os reflexos do surgimento de espaços de livre escrita, como os blogs e os selos editoriais, para a inserção de personagens e de escritoras lésbicas no espaço literário brasileiro. A escolha de Dias se deu primeiramente pelo fato de ser uma escritora lésbica que fez a transição da escrita virtual para os livros, porém tal escolha também se deu pelo sucesso que ela possui com as leitoras de livros lésbicos e pelo volume de obras que ela publicou tanto na internet quanto impresso.

Eliana Natividade Carlos, nascida no Rio de Janeiro em 09 de janeiro de 1979 e hoje residente em São Paulo, escreve na internet sob o pseudônimo Karina Dias desde o ano de 2007. A autora é jornalista formada pela Universidade São Judas Tadeu, hoje faz mestrado em Jornalismo Contemporâneo na Faculdade Cásper Líbero e também se dedica à publicação de seus livros.

Dias iniciou a publicação de seus textos na internet quando conheceu, por intermédio de uma amiga, o site lésbico XanaInBox $(X i B)$, hoje em dia desativado, mas que funcionou entre os anos de 2000 e 2009. O XiB fazia parte do GLSPlanet, um site pertencente ao portal Terra que agrupava diversos blogs que versavam sobre o universo homossexual. O XanaInBox era um site colaborativo de divulgação e leitura de textos lésbicos. Qualquer pessoa podia se cadastrar no site e criar um perfil, através do qual estava apta a publicar textos e a comentar as histórias já publicadas.

Em entrevista ao programa As Brejeiras, Karina afirmou que escrevia textos com personagens lésbicas desde os quatorze anos, porém "escrevia e guardava, não mostrava para ninguém. 


\section{Ismênia de Oliveira Holanda}

\section{Antonio Crístian Saraiva Paiva}

Eram poucas as pessoas que tinham visto os meus escritos" (AS BREJEIRAS, 2011). A sua relação com a escrita de textos ficcionais se iniciou quando ela cursava a quinta série, por influência de uma professora de Português que a obrigou a ler um livro todo. Antes disso, ela afirma que achava a leitura algo chato, porém a partir desta experiência não mais parou de ler e escrever textos. (PROGRAMA..., 2009).

Essa sua predileção pela escrita aumentou quando completou quinze anos e pediu de presente ao pai uma máquina de escrever, ao invés das tradicionais viagens ou festa de quinze anos. Segundo ela, tal pedido contrariou a sua mãe, que desejava ver a filha com aqueles clássicos vestidos de festa, porém o seu pai gostou da ideia e lhe presenteou com a máquina de escrever. Dias afirma que a partir de então passou a andar com aquele presente debaixo do braço e que começou a escrever com mais frequências, porém ela escrevia suas histórias e as guardava sempre (PROGRAMA..., 2009). Tal paixão pela escrita fez com que aos dezenove anos ela escrevesse um romance com a temática lésbica. Sobre esta história, que durante muitos anos ficou guardada, a autora afirma que só a mostrou para uma amiga, que a incentivou a seguir escrevendo.

Ocorre que esta sua incursão na escrita, mesmo com o apoio do seu pai, era uma atividade em certo sentido solitária, pois a autora raramente mostrava seus textos para as pessoas, ficando apenas para si, pelo prazer de escrever. Sobre a atividade da escrita, Lejeune (2014) afirma:

Escrever, creio eu, não é apenas um exercício mecânico, um saber construir - isso, o hábito de leitura permite a quase todos nos fazer mais ou menos bem -, escrever é, sobretudo, ter a sua própria voz, o seu estilo, sua identidade. (...) Existe um parentesco entre o ato de escrever e a experiência de se soltar. (LEJEUNE, 2014, p. 234)

Creio que "se soltar" no sentido atribuído por Lejeune, para os textos lésbicos e, especificamente, para a autora em questão, é uma atividade de refletir sobre a sua própria sexualidade, sobre a sua afetividade e sobre como ela é pouco representada na literatura em nossa sociedade.

Sobre o ato da escrita de textos por mulheres e o fato de muitos destes serem guardados e, em certo sentido, invisibilizados ou secretos, Cixous tece algumas considerações sobre o motivo que leva tais mulheres a fazer isso. Segundo a autora, há um pensamento, em certo sentido bobo, que faz as mulheres terem vergonha de sua escrita:

Besides, you've written a little, but in secret. And it wasn't good, because it was in secret, and because you punished yourself for writing, because you didn't go all the way, or because you wrote, irresistibly, as when we would masturbate in secret, not to go further, but to attenuate the tension a bit, just enough to take the edge off. And then as soon as we come, we go and make ourselves feel guilty-so as to be forgiven; or to forget, to bury it until the next time. (CIXOUS, 1976, p. 876-877, grifos nossos)

Cixous conclama a escrita por parte das mulheres dizendo "Write yourself. Your body must be heard." (CIXOUS, 1976, p. 880). Para a autora, a escrita feminina é um contraponto ao discurso, não somente literário, centrado no homem. A escrita 


\section{Ismênia de Oliveira Holanda}

\section{Antonio Crístian Saraiva Paiva}

seria, então, uma forma de a mulher não somente escutar e (re)encontrar o seu próprio corpo, mas também de repassar essa experiência para outras. Machado (2009), citando Cixous, afirma que "uma vez recuperada a sua sexualidade e libertando-se do discurso centrado no falo, a mulher alcança a sua identidade e a produção literária feminina torna-se inesgotável" (MACHADO, 2009).

A internet e a quebra de barreiras para a comunicação que ela trouxe está sendo um meio de atenuar esta dependência material para a produção da escrita. Apesar de ser necessário um computador para publicar na internet, este é um bem que está disseminado amplamente em nossa sociedade, seja em casa, escolas, trabalho ou lanhouses. Além disso, há um amplo acesso a sites através de celulares, que também são utilizados para a produção de textos, principalmente curtos, como no caso do Twitter.

No caso de Eliana, o ato antes solitário de escrita deixou de ser solitário e passou a ser partilhando, quando, no final de 2006, ela acessou o XiB. Ao entrar em contato com este site, ela, que já vinha escrevendo textos lésbicos em sua máquina de escrever desde os quinze anos, passou a ler os textos lésbicos nele contidos.

No primeiro contato com o site, Eliana apenas lia os textos, porém, ela afirma

quando eu encontrei esse site, aí eu comecei a pensar na possibilidade de postar as minhas histórias, mas eu não postei aquela que eu tinha escrito lá atrás, postei uma nova. Aí eu escrevia no próprio site e postava, era um capítulo por dia. Achei que ninguém ia ler (KARINA DIAS, entrevista em 29/04/2014).
Quando, no início de 2007, ela resolveu começar a publicar no XiB foi necessário criar para si um login de acesso ao site. Como ela já havia percebido que este login podia ser um nome inventado ou um apelido, resolveu criar para si um pseudônimo, não para esconder a sua identidade, mas por poder modificar o seu nome de batismo, que não a agradava. Nascia aí a escritora Karina Dias.

Sobre a importância do uso de pseudônimos no contexto de produção da escrita na internet, Schittine (2004) afirma que

\begin{abstract}
A maneira que muitos diaristas virtuais encontraram de aumentar a intimidade com o leitor e de se preservar ao mesmo tempo é o uso do pseudônimo. Na rede, é comum que o pseudônimo seja uma espécie de apelido, uma redução do nome ou apenas o uso de iniciais, o que serve para destacar uma das facetas do eu (...) O pseudônimo não deixa de ser um segundo nome para o mesmo autor. (SCHITTINE, 2004, p. 105)
\end{abstract}

Quando questionada sobre a formação deste seu "segundo nome", ela afirma não o ter feito por medo de sofrer preconceitos seja na família, seja na sociedade:

É engraçado, né, assim, algumas pessoas até falam 'ela adotou um pseudônimo porque ela tinha medo do preconceito', uma coisa desse tipo. Mas, não, minha explicação é bem mais simples: Karina, porque é um nome que eu gosto muito, e Dias, porque um dia eu estava assistindo um programa, o Globo Esporte, e aí estava passando uma reportagem sobre o Vasco, que é o time que eu torço, Vasco da Gama. Aí tinha um jogador que se chamava Alex Dias e eu já tinha escrito o primeiro capítulo para eu postar num site do 
Terra, que foi o primeiro site que eu vi na minha vida de literatura lésbica. Aí eu vi que poxa, aqui a gente pode usar o nome que quer. Aí eu fiz esse login para me cadastrar e começar a postar as histórias com esse nome. Eu não precisava usar o nome que eu não gostava que é Eliana. Eu não gosto, mamãe podia ter sido mais generosa. (KARINA DIAS, entrevista em 29/04/2014).

Entre os anos de 2007 e 2012, Karina Dias publicou mais de dez textos com temática lésbica na internet e logo se transformou na escritora mais comentada do Xana In Box e, com o fim deste em 2009, passou a publicar e a fazer sucesso também no site Livre Arbítrio. Suas histórias chamavam atenção pelo conteúdo e também pela quantidade e periodicidade nas publicações.

O fato de trabalhar em uma locadora de vídeos fez com que a autora gostasse muito de assistir filmes românticos, o que ela admite e pode ser constatado quando se percebe os títulos de seus textos. Todos os títulos de seus livros são nomes de filmes, como De repente amor, Quando o amor acontece, Simplesmente irresistivel, No ritmo do amor, etc. Somente sua última obra As rosas e a revolução não possui o mesmo título que um filme, pois este título foi escolhido pela esposa da autora que sempre a acompanha e incentiva no seu trabalho de escrita.

Esse sucesso na produção de textos no site começou a render frutos logo no ano de 2008, quando houve uma enquete no site lésbico Bolacha Recheada em que se perguntava quais foram os melhores contos publicados no XiB no ano de 2007. A história No ritmo do amor foi a campeã na votação, o que deu visibilidade ainda maior para a autora nos meios de divulgação da cultura lésbica (SITE..., 2009). Tal fato pode ser confirmado pela fala de Laura Bacellar, uma das donas da Editora Brejeira Malagueta, que quando questionada sobre a publicação do texto No ritmo do amor, publicado pela editora com o nome de Aquele dia junto ao mar em 2009, nos fala sobre essa votação na internet:

\begin{abstract}
- Hoje vocês pedem que os originais enviados sejam de livros não publicados na internet, entretanto, o livro "Aquele dia junto ao mar" foi publicado primeiramente na internet e foi modificado para depois ser publicado por vocês. Qual é a relação de vocês com essas autoras que publicam em blogs?

A gente prefere um original inédito, mas consideramos algo já publicado online se houver qualidade e tiver gerado muito interesse. Foi o caso de Aquele dia junto ao mar, que foi votado o texto mais querido das leitoras no ano de 2008 num site imenso, com milhares de postagens. Uma indicação como essa é valiosa para nós, já que demonstra o gosto de muitas leitoras. Em princípio queremos criar uma sinergia com os sites literários para lésbicas, mas os meios são um pouco diferentes e nem tudo o que cai na rede serve para o papel. A internet não é crítica e suporta muita porcaria. Nosso trabalho é triar o que merece ficar impresso por anos e anos. (HOLANDA, 2012)
\end{abstract}

Mesmo que desde nova tenha começado a escrever histórias de amor lésbico, Karina Dias afirma que antes de passar a ler e publicar no $X i B$ nunca tinha lido nada do tipo. Percebendo-se lésbica, ela sempre lia romances heterossexuais e pensava em uma mudança de personagens, reescrevendo as histórias em sua mente como se os casais fossem formados por duas mulheres. Segundo 
ela, os livros que conhecia eram livros gostosos de ler, mas não a representavam, o que a incomodava:

\begin{abstract}
Então, eu não tinha lido... Antes de escrever literatura lésbica eu não tinha lido nada do gênero. E é curioso, toda vez que eu lia um romance eu sempre, na minha cabeça, tentava trocar o personagem masculina por outra personagem feminina e aí eu achava aqueles romances lindos, maravilhosos, mas eu não, era gostoso de ler, mas ao mesmo tempo não me representava. E um dia uma amiga me apresentou esse site do Terra, que foi eu comecei a escrever, e eu fiquei maravilhada, porque eu nunca tinha lido nada a respeito, foi a primeira vez que eu tive contato com a literatura lésbica foi através desse site. E eu fiz meu pseudônimo, fiz meu login e comecei a escrever lá. (KARINA DIAS, entrevista em 29/04/2014).
\end{abstract}

Foi este incômodo com o fato de não se sentir representada nos livros que lia e o gosto pela leitura e por filmes românticos que fizeram com que ela começasse a escrever histórias de amor entre mulheres, para si. Nas palavras da própria autora, ela diz

sempre quis ler uma história de amor entre duas mulheres, porque eu amo mulheres, eu me relaciono com mulheres (...) eu sempre quis ler essas histórias e não tinha. Poxa, sacanagem. Não tem, então, eu vou produzir, então vai ter! (KARINA DIAS, entrevista em 29/04/2014)

Este inconformismo como ato produtor de textos literários já foi debatido nos campos das ciências humanas, como no exemplo da importante obra de Nicolau Sevcenko, Literatura como missão. Uma das conclusões a que chega o autor é que
Outros efeitos decorrem ainda desse poder alegórico da literatura. Todo discurso criativo assinala um ato fundador, na medida em que nomeia situação e elementos imprevistos, conferindo-lhes existência e lançando-os na luta por um espaço e uma posição, no interior das hierarquias que encerram as palavras encarregadas de dizer o mundo conhecido e compreendido. Produzir literatura criativa é por isso um gesto de inconformismo. (SEVCENKO, 1983, p. 247)

$\mathrm{O}$ início de sua missão enquanto escritora na internet ocorreu com a escrita e publicação diária do romance De repente é amor. Mesmo já tendo antes escrito um texto lésbico, a autora optou por publicar no site um texto novo. O seu primeiro texto escrito foi posteriormente publicado no site quando a autora já era conhecida nos sites de literatura lésbica sob o título Quando o amor acontece.

De repente é amor é uma história que inicialmente teria apenas três capítulos, mas dado o imediato retorno das leitoras através do site e de e-mails, a autora prolongou a história, que foi publicada ao longo de mais de um mês, diariamente. Foi a partir da repercussão da história com as leitoras que Karina Dias passou a perceber a importância de escrever textos com personagens lésbicas e que não passassem uma imagem negativa da homossexualidade, e sim que houvesse um reconhecimento das lésbicas enquanto cidadãs normais.

Iniciou-se, assim, um estreito contato com as suas leitoras através do seu e-mail. A partir desta interação virtual com as leitoras, a autora pôde perceber que por ela não sofrer preconceito no ambiente familiar por ser lésbica, isso não quer dizer que outras

Dossiê Literatura e Memória 


\section{Ismênia de Oliveira Holanda}

\section{Antonio Crístian Saraiva Paiva}

mulheres não sofram. Tal percepção a fez entender que seus textos, algo tão pessoal, poderiam se transformar em instrumento de militância, ao mostrar para mulheres que é normal ser homossexual.

Isso a fez perceber que realmente precisava escrever sobre a realidade de mulheres que amam mulheres, mostrando que elas podem ser felizes, ser normais como qualquer outra pessoa. Daí o carinho tão grande que a autora tem por este seu primeiro texto publicado na internet, pois foi a partir dele que ela passou a perceber a sua literatura como uma literatura de militância. Segundo ela,

as leitoras começaram a me mandar um monte de emails e os e-mails, eles vinham carregados de desabafo, sabe. A maioria delas não aceitava a sua sexualidade e falavam "poxa a sua personagem é tão, ela se afirma homossexual, ela não tem vergonha disso. Ela corre atrás dos objetivos dela. O problema dela não é ser homossexual. Ela tem problemas de tirar, notas baixas, qualquer coisa, mas não é necessariamente ser homossexual." E esses e-mails me deram, a partir desses e-mails eu comecei a pensar "poxa, eu não enfrento preconceito e, talvez, eu escrevendo, escrever é a minha paixão, eu acho que eu não conseguiria viver sem escrever. Então, se eu posso, com uma caneta e um papel na mão, de repente, apresentar para essas pessoas um mundo normal, de mulheres que amam outras mulheres, mas que sofrem, que choram, que trabalham, que riem, que fazem tudo que todo mundo faz, a única diferença delas é que na hora de dormir elas dormem com uma pessoa do mesmo sexo. (PROGRAMA... , 2009)
Tzvetan Todorov nos fala dessa importância da literatura como forma de reconhecimento de si. Para o autor, a literatura estende as mãos para aqueles que estão deprimidos, assim como nos torna mais próximos daqueles que nos cercam, ajudando a compreender o mundo e a nele melhor viver. Todorov afirma sobre a literatura: "não que ela seja, antes de tudo, uma técnica de cuidados para com a alma; porém, revelação do mundo, ela pode, também, em seu percurso, nos transformar a cada um de nós a partir de dentro." (TODOROV, 2009, p. 76-77)

Este contato com as leitoras e as mudanças que a literatura trouxe para a vida de Dias foram tão importantes que ela chegou inclusive a conhecer a sua esposa através do XIB. Foi este casamento que fez com que a autora se mudasse no ano de 2008 para a cidade de São Paulo, onde reside até hoje.

Além deste projeto de fazer com que seus textos sejam uma forma de reconhecimento por parte das lésbicas, há também uma preocupação por parte da autora de que sua obra seja absorvida por pessoas heterossexuais. Com isso ela busca que tais pessoas percebam a naturalidade dos relacionamentos lésbicos e possam entendê-los como uma forma comum de amor. Esta tentativa, segundo diz a autora, tem se efetivado, pois parte de seus leitores que enviam e-mails não são mulheres homossexuais, há também heterossexuais. Segundo ela, seus textos constituem uma

literatura de militância, na verdade eu procuro colocar sempre nas minhas histórias o cotidiano de, das mulheres que amam outras mulheres e pronto. É que tudo que a gente escreve é político, não tem como a gente fugir da política, nesse momento que a gente está conversando a gente está fazendo política. Não tem como a gente não estar fazendo política. 
Então, assim, eu trabalho nas minhas histórias para diminuir o preconceito. Eu tenho muito leitores que são heterossexuais também e quando eles leem as minhas histórias falam "é igual a minha vida, só muda um detalhe: com quem a pessoa dorme, com quem ela se relaciona sexualmente". (...). Para acabar, para acabar é difícil acabar com alguma coisa, mas para diminuir o preconceito. Eu acho que é esse tipo de militância da literatura lésbica. (KARINA DIAS, entrevista em 29/04/2014).

Vange Leonel, cantora, jornalista e escritora, foi um exemplo de como textos voltados para o público lésbico podem ser lidos por outros públicos e em grandes meios de comunicação. Leonel colaborou com colunas de tema lésbico para as revistas masculinas Sui Generis e G Magazine, para o jornal Folha de S. Paulo e para o portal LGBT Mix Brasil. Segundo a Leonel, esse interesse de outros públicos por seus textos se deu porque ela descobriu que

Podia escrever colunas sobre homossexualidade, adicionando lirismo, humor, sem ser militante, pedante ou chata. A recepção que tive foi ótima. Acredito que a vida como lésbica fora do armário me ensinou a tratar o assunto de maneira firme, mas sem ser grossa, o que faz com que minhas colunas e textos sejam bastante apreciados por heterossexuais também. Nunca gostei de retratar gays como vítimas, nem me interessa cavar um fosso intransponível entre héteros e homossexuais. (PÉRET, 2012, p. 79)

Diante do sucesso no $X I B$, Karina Dias passou também a publicar seus textos em uma comunidade do Orkut chamada Histórias e Desabafos, na qual se reuniam leitoras e escritoras de textos lésbicos. A postagem de textos no Orkut passou a ser quase simultaneamente que no site. Segundo o que me disse a autora em entrevista, os seus textos somente foram publicados por ela no site XanaInBox, na comunidade Histórias e Desabafos no Orkut e nos Sites Livre Arbitrio, Fator X e ABCLes. Entretanto, diversos textos dela podem ser encontrados em outros sites, assim como nas comunidades de seus fãs no Orkut e na rede social exclusivamente lésbica Leskut. Isso ocorre porque fãs copiavam suas histórias e divulgavam em outros sites lésbicos, fazendo com que a autora nem saiba ao certo em quais sites suas histórias estão publicadas hoje em dia.

Em geral, tais fãs informam de quem é a autoria do texto. Porém já houve casos de plágio de textos lésbicos publicados na internet. Por exemplo, Dias teve um texto seu republicado em outro site lésbico e com o nome das personagens trocados, assim como outra pessoa assumiu a autoria do texto. Logo que o plágio foi descoberto, os responsáveis pelo site foram informados e retiraram o texto do ar, pedindo também desculpas para a autora. Já a pessoa que publicou o texto como sendo seu também pediu desculpas pelo ocorrido e disse que não sabia se tratar de plágio. Por isso a autora, assim como diversas outras autoras que estão publicando na internet, depositam cópias de seus textos no Escritório de Direitos Autorais (EDA) da Biblioteca Nacional.

Depois da publicação de seu primeiro livro impresso em 2009, Dias participou no ano de 2011 da primeira coletânea de textos lésbicos da América Latina. Trata-se do livro Voces para Lilith, no qual foi publicado o seu conto Al encuentro del amor. Em 2012, a autora novamente volta a publicar um romance impresso pela Editora Brejeira Malagueta com o título Diário de 


\section{Ismênia de Oliveira Holanda}

\section{Antonio Crístian Saraiva Paiva}

uma garota atrevida. Essa obra, segundo informado pela esposa da autora quando conversamos em São Paulo, é o início de uma trilogia contando a vida de uma mulher lésbica, desde a sua descoberta enquanto homossexual até a vida adulta.

O ano de 2014 foi para a autora muito importante em termos profissionais, pois ela saiu de seu emprego como jornalista para se dedicar ao mestrado em Jornalismo Contemporâneo e a divulgação e venda de seu terceiro romance impresso, As rosas e a revolução. Esta obra foi lançada de forma independente e está sendo comercializadas prioritariamente pelo novo site da autora.

Nos meses de abril e maio de 2014, esta obra teve dois lançamentos, um em São Paulo, no dia 24 de abril, na Livraria Blooks, no Shopping Frei Caneca, e no Rio de Janeiro, no dia 02 de maio, na Livraria Cultura. A tiragem inicial desta obra foi de mil exemplares, e a autora faz questão de fazer uma dedicatória para cada fã que o está comprando em seu site. Segundo ela, com o dinheiro arrecadado com a venda de tais livros ela pretende financiar a publicação de outras histórias suas, como as que já foram publicadas na internet.

Ainda no mês de maio de 2014, houve o lançamento da segunda coletânea de textos LGBTs em que Karina Dias foi selecionada. Trata-se da obra Orgias Literárias da Tribo, que foi lançada em um stand no espaço da Feira Cultural LGBT, evento que compõe a Parada da Diversidade Sexual de São Paulo e do qual participei. Assim, quando estive em São Paulo para entrevistar a autora, pude também visualizar alguns momentos de contato pessoal entre a autora e suas fãs.

Comparando seus textos de hoje em dia com os que produzia à época da escrita diária em blogs, Karina Dias me disse que hoje se preocupa mais com a ortografia. Antes ela somente pensava na mensagem que estava passando, pois na internet as pessoas entendem a mensagem independente da linguagem escrita formal, haja vista que há uma escrita informal e mais rápida em uso na internet. $\mathrm{O}$ que faz com que as pessoas entendam a mensagem mesmo que contenha muitas abreviações ou erros de grafia ou de ortografia. Além disso, a autora tinha dificuldades de manusear as ferramentas da internet:

$\mathrm{Eu}$ assim, naquela época, eu nem sabia direito mexer na internet. Eu ainda usava a minha maquina de escrever, para você ter uma ideia. Aí eu comecei a escrever direito, eu não passava no Word porque, porque eu achava que eu não ia conseguir copiar e colar, também nunca tentei. Burrice mesmo. E eu achava bacana aquele negócio de não reler a história, porque eu não reli nenhum destes capítulos que eu postei.

É, agora eu estou relendo e, assim, assustadíssima. Eu vou rever um monte de coisa. Mas eu não relia porque eu achava que se eu relesse eu, uma coisa meio louca, né, eu ia mudar. Toda vez que eu releio uma história eu mudo. Então, a minha intenção era deixar a primeira ideia. Então, todas essas histórias que foram pra internet elas não têm nenhuma alteração, foi a primeira ideia. Por isso que elas não foram reescritas. Então, assim, foi a primeira ideia, eu estava pensando, digitando e cliquei em postar. (KARINA DIAS, entrevista em 29/04/2014).

Desde 2012, a autora não coloca mais textos novos na internet. Quando questionada sobre isso, ela afirmou que pretende continuar publicando na internet, porém no site, fazendo uma divisão entre os textos que serão para internet e aqueles que serão 


\section{Ismênia de Oliveira Holanda}

Antonio Crístian Saraiva Paiva

impressos. Ela pretende fazer histórias mais curtas para a internet e histórias densas para livros.

Na sua escrita atual, a autora diz que tem mais preocupação com a pesquisa, além da ortografia. Seu último livro foi fruto de uma pesquisa de seis anos. Esta pesquisa se iniciou quando ela, na condição de estudante de graduação em Jornalismo, foi bolsista de um projeto que estudava a relação da mídia com a Ditadura Militar no Brasil. Ela foi bolsista CNPq, tendo escrito uma monografia sobre o tema e está atualmente pesquisando para a dissertação sobre a relação entre Mídia e Ditadura.

Mesmo estando hoje em dia voltada para a publicação de seus livros, quando questionada sobre o fato de ser uma escritora profissional, Dias afirma que não o é. Ao perguntar sobre o seu trabalho de escrever, Dias me informou que não se considera escritora, visto que a escrita para ela é algo pessoal e político, dada a importância que tem para a vida das leitoras e para a sua própria vida. Nas palavras de Dias:

Não, de forma nenhuma. Nem hoje eu me vejo como escritora profissional. Não. Amadora, sempre aprendendo. Eu sou jornalista. Escritora é amadora mesmo. Não sei. Não sei se um dia eu vou ser uma escritora profissional. É, é difícil. É porque escrever para mim é um hobby, não é um trabalho, assim, não é trabalhoso, é uma coisa muito prazerosa, é uma coisa que me dá muita, muita, alegria. Eu me emociono quando eu escrevo, então, isso não tem preço. (KARINA DIAS, entrevista em 29/04/2014).

Além disso, ela afirma saber que não vai viver da literatura, pois o autor ganha somente $10 \%$ do que é vendido do livro e seu livro mais vendido pela Editora Malagueta teve três tiragens, cada uma de mil exemplares.

Interessante é fazer uma reflexão sobre o que é ser autor para esta escritora. Nas falas de Karina Dias fica claro que ela não se considera como tal, por não ter a escrita como única profissão. Então, diante disto, é preciso entender o que significa simbólica e politicamente em sua trajetória o fato de ser lida pelo público para o qual elas estão voltadas.

Pode-se perceber no seu discurso que a escrita é um imperativo, uma necessidade. $\mathrm{O}$ que não retira o aspecto coletivo de tais textos, pois se pode teorizar que a "necessidade" de escrever textos lésbicos é fruto da percepção da inexistência de tais personagens em livros.

É importante entender como tem ocorrido um processo de fomento de uma escrita pessoal e política na qual a internet é um meio de romper as barreiras, antes tão rígidas, entre produção e consumo de textos literários. Pode-se perceber que, nestes anos de crescimento do acesso a internet e de produção escrita em blogs, a escrita tem se modificado, assim como a própria lógica do mercado editorial, que envolve, entre outros, leitores escritores e editores.

O grupo de escritoras do qual Karina Dias faz parte tem em sua trajetória de escrita aspectos em comum. Ela se inicia com a leitura de textos, a percepção da ausência de textos lésbicos, a produção de textos lésbicos para si (guardada), a descoberta de espaços virtuais de literatura/escrita de textos lésbicos, a leitura e a escrita de textos nestes sites e blogs e, por fim e para algumas, a publicação de textos em forma impressa. 


\section{Ismênia de Oliveira Holanda}

Antonio Crístian Saraiva Paiva

Cabe ressaltar que tal publicação não ocorre somente através de selos específicos (como Edições GLS e Alethéia) ou das Editoras Brejeira Malagueta e Divers@. Há autoras que publicam por si mesmas com recursos próprios e há aquelas que também publicam com auxílio de editais ou ações de fomento à cultura, como os das Prefeituras de Blumenau, Fortaleza e São Paulo, que publicaram as obras Boleros de papel, Fortaleza de todos os amores e Orgias literárias da tribo, respectivamente, todas elas de autores assumidamente homossexuais e com conteúdo voltado para o público LGBT.

\section{Considerações Finais:}

Há diversas formas de problematizar sobre a sociedade. E a produção cultural, é uma das formas que, mesmo não sendo científica, é válida para problematizar sobre o cotidiano. Penso que especialmente a literatura é uma destas formas não científicas pela qual podemos acessar não somente questões importantes para os estudos da arte em si, mas também as disputas pelo predomínio narrativo e do controle do imaginário, mostrando-nos disputas existentes em outros campos sociais, tornando-se um fértil campo de estudos para a Sociologia.

A literatura muitas vezes tem uma função de legitimação das diferenças sociais, principalmente através do chamado cânone literário, que categoriza uma série de livros como sub-literatura. Pode-se perceber que a categorização destas obras voltadas para o público lésbico como sub-literatura ou para-literatura ocorre não somente por serem obras voltadas para um grupo homossexual, mas também pelo fato de tal escrita ter uma forte relação com a escrita do e para o feminino (BRANCO, 1991).

Se partirmos dos ensinamentos de Koselleck (2013) quando afirma que as coisas não são, mas que as coisas estão sendo, estão acontecendo, e este acontecimento se dá no tempo e que a realidade é algo que existe em movimento e este movimento precisa ser observado, podemos entender que o passado já não é mais uma permanência e que o futuro é um desejo de mudança. E tal mudança, tal desejo, em relação à literatura lésbica é pautado na mudança, na construção de novas possibilidades de construção de personagens.

Com esta valorização do novo, não um novo modelo, mas um campo de possibilidades de construção de personagens lésbicas, há um reconhecimento automático do antigo, pois somente sabe-se o que é novo se sabemos o que é o passado (KOSELLECK, 2013). E é neste campo de disputas entre a fronteira do novo com o passado que são construídas as novidades. Novidades estas que não são inesperadas, mas que estão no fluxo da vida.

A escrita de livros voltada para mulheres homossexuais pode ser compreendida, inicialmente, como algo novo, uma mudança repentina, porém é necessário entender a história deste movimento de afirmação de lésbicas na literatura. Se antes tínhamos representações estigmatizadas da homossexualidade, a busca por uma nova representação está fincada no reconhecimento deste passado, que de fato ainda é presente. A escrita da presente literatura lésbica, que visa um futuro diferente para as vidas de suas leitoras, é uma escrita com os olhos no passado. Tais olhos buscam mãos e mentes que reescrevam histórias lésbicas, história 


\section{Ismênia de Oliveira Holanda}

Antonio Crístian Saraiva Paiva

de descobrimentos e de amores, porém não histórias com finais moralizantes e tristes para as personagens homossexuais e que busque as colocar em um lugar social de exclusão.

Se de um lado as grandes editoras reclamam das dificuldades de vendas após o advento da internet, outras editoras e autores, tentam com a internet uma aproximação com o público e uma fidelização do mesmo. Assim, a rede virtual deixa de ser um obstáculo e se torna uma ponte para a venda de obras impressas e para a divulgação da homocultura. Essa realidade não ocorre somente com os livros lésbicos no Brasil, mas também com livros voltados para o público jovens, que utilizam a internet para se aproximar do público leitor jovem que está cada dia mais conectado e que mesmo assim consome livros enquanto bens culturais de status.

Percebe-se nas obras de Dias e na sua trajetória é que a questão da trajetória pessoal perpassa sua trajetória literária e que o contato com o público, com suas angústias, medos, vivências, felicidades, foi sendo incorporado nas personagens da autora. Karina Dias afirma não ter sofrido tanto a pressão da família quando da descoberta da sua homossexualidade, porém elas nos mostra, através de suas personagens, as dificuldades da não aceitação de si e não aceitação da família no tocante à homossexualidade feminina.

Por mais que seus textos sejam fruto da sua vontade de ver personagens homossexuais como ela em livros, tais personagens não são somente fruto de experiências individuais, mas são a condensação de uma gama de experiências vivenciadas por jovens homossexuais no Brasil atual. Assim, seus textos não devem ser vistos apenas como um divertimento para aquelas mulheres que já são assumidas e lidam bem com o fato de pertencer a uma minoria sexual.

Seus textos podem ser entendidos também como uma forma de passar uma ideia de positividade sobre a homossexualidade para aquelas jovens mulheres que ainda não lidam muito bem com o fato de pertencer a uma minoria sexual. Além disso, as vivências e meios de transpor os preconceitos que as personagens vivenciam, são formas de ensinamentos, de transpor o papel e mostrar a pessoas que estão no processo de descoberta de si, de luta contra o preconceito dentro e fora de casa, de terem forças e perceberem que é possível uma vida homossexual feliz. O que se pode perceber é que há uma mensagem política com o uso de finais felizes em tais obras. A mensagem final que se passa é que o amor vale a pena e que se deve lutar por ele, pois somente se pode ser feliz quando se respeita quem se é, como se é, amando que se ama.

Tais textos têm uma importância do ponto de vista pessoal, tanto da autora, quando das leitoras, mas também são importantes do ponto de vista coletivo, para a cultura de grupo relacionada às lésbicas. Pode-se perceber que há um fomento da homocultura, da produção cultura de livros, filmes, séries de TV, peças de teatro, etc, que têm como eixo central a existência de pessoas homossexuais. Entendo que o melhor seria não necessitar existir essa distinção entre a cultura em geral e a homocultura, porém, esta distinção ainda se faz necessária, pois vivemos em uma sociedade que não aceita plenamente a diversidade sexual e nem a diversidade cultural.

Por mais que o trabalho de Karina Dias se centre no público lésbico, ela busca-se fazer com que tais obras sejam lidas 


\section{Ismênia de Oliveira Holanda}

Antonio Crístian Saraiva Paiva

por pessoas que não fazem parte deste grupo, a exemplo das resenhas dos livros em sites/blogs de leitores não pertencentes ao universo homossexual. Com isso a autora visa um maior reconhecimento de si e de suas obras, porém não deixando de deixar explícito a questão da homossexualidade feminina, sua e de suas personagens.

Eis aí uma diferenciação entre as escritoras que compõe a leva de escritoras da qual Dias faz parte e outras artísticas que são homossexuais e não fazem disso uma bandeira cultural, política ou identitária. Não se busca fazer aqui um juízo de valor, colocando as escritoras assumidamente homossexuais e que produzem para o público lésbico como mais importantes que aquelas que são lésbicas, mas não levam isso como marca de sua produção. $\mathrm{O}$ que se afirma é que a não representação de mulheres lésbicas na literatura fez surgir, entre o grupo de mulheres lésbicas que tinham a internet como local de socialização, a necessidade de produção de personagens nas quais se vissem representadas.

Existe uma carência na representação destas mulheres, não somente no âmbito das relações sociais, mas também na representação cultural. A essa necessidade, posteriormente, veio a socialização destes textos, constituindo o que se pode chamar de escritoras lésbicas. Destas, pode-se perceber que Karina Dias é um exemplo interessante de como essa necessidade e percepção de ausência de personagens lésbicas, assim como o advento de blogs e sites específicos, foi utilizado de forma fazer com que ela fosse reconhecida nos meios lésbicos como uma escritora que "fala pelas lésbicas", "que mostra experiências de nossas vidas", "que nos entende como somos", ou seja, uma profissional da representação
A autora soube se utilizar de uma necessidade, que também era sua, e esta necessidade se transformou em um mercado de nicho com o advento da Editora Malagueta em 2008. Por mais que a autora diga que não é uma escritora profissional, pode-se perceber que houve uma profissionalização de sua escrita no decorrer de suas obras, como já foi explicitado através dos romances analisados. Seus romances passaram de história escritas e publicadas diretamente numa plataforma virtual (XanaInBox) para romances escritos, reescritos, revisados e editorados, o que modificou consideravelmente a escrita, a correção de linguagem e, principalmente, a forma de acesso ao texto.

Esse momento de escrita em blogs e sites específicos, com o uso de pseudônimos, parece ser o precursor do momento atual, no qual diversas autoras em blogs, sites e livros, não usam pseudônimos e buscam mostrar quem são, suas histórias e vidas. A internet é ponto chave no traçado desta nova representação de lésbicas na literatura brasileira, pois o elemento propulsor da produção e divulgação de textos e autoras é a existência de espaços virtuais de socialização lésbica. A internet não é mais vista como uma forma de "armário", no qual estas mulheres estão para esconder a sua sexualidade, mas sim como uma ponte na qual descobrem novas sociabilidades e formas de viver.

Ocorre que estes espaços de socialização e leitura não permanecem apenas na própria internet. A editora Malagueta, por exemplo, fez uma aposta ao publicar de forma impressa um livro de Karina Dias que já havia sido publicado na internet. E tal aposta, se mostrou frutífera, pois a obra é a que mais vende até hoje da editora, estando em sua terceira tiragem. 


\section{Ismênia de Oliveira Holanda}

\section{Antonio Crístian Saraiva Paiva}

Mesmo com a publicação de livros impressos, o que afasta a autora de seu público leitor original, pois não há mais comentários a cada capítulo que é escrito, como havia quando os textos eram publicados na internet, a autora ainda buscou manter uma fidelização e um contato próximo com o seu público. Para isso ela tem vendido o seu terceiro livro impresso em seu site e autografado todos que são comprados. Além disso, com a publicação de tal obra, Dias tomou parte, além do processo de escrita, do processo de editoração, impressão e distribuição da obra.

Diferentemente do que eu pensava antes de entrevistar a autora, ela não afirma ser uma escritora profissional, mas sim amadora. Tal afirmação leva a pensar sobre a própria condição dos autores em nossa época. Mesmo que estudos nos mostrem que é difícil para escritores vivam somente da sua escrita literária, vivendo de atividades ligadas à escrita, como o jornalismo e a publicidade, mesmo assim tais pessoas se consideram escritores.

Importante notar que mesmo com um bom volume de obras vendidas e com a visibilidade que tem nos meios lésbicos, prevalece na fala de Dias a escrita como prazer, como imperativo de si e como uma afirmação política de grupo. Por mais que exista a vontade de ser reconhecida por suas leitoras e que esse grupo cresça, percebe-se que o intuito maior da escrita lésbica neste momento é o fomento de si enquanto produção artística e identitária.

Mesmo que a literatura lésbica não seja considerada um gênero literário, ela é efetivamente um gênero de mercado. Além disso, a criação de um nicho de mercado, com um público leitor específico, é uma questão identitária. E essa produção cultural de nicho é criadora de modos específicos de ver e viver a homossexualidade feminina. Temos, então, com o advento e crescimento da chamada literatura lésbico um processo de afirmação identitária por parte das lésbicas leitoras e produtoras destes textos e um processo de identificação, de reconhecimento e aceitação, por parte o público leitor formado por pessoas heterossexuais.

\section{REFERÊNCIAS}

ANDRADE, Giana Franco de. A desconstrução do sujeito na Obra as Traças de Cassandra Rios. Disponível em: <http://www.webartigos.com/artigos/a-desconstrucao-do-sujeitona-obra-as-tracas-de-cassandra-rios/62214/> Acesso em: 12 agos 2014

AS BREJEIRAS - Programa 07. Direção Laura Bacellar e Hanna Korich. Produção: Laura Bacellar e Hanna Korich. São Paulo: Editora Brejeira Malgueta, 2011. Disponível em: < http://www.youtube.com/watch?v=DSieBaHxlzk $>$ Acesso em: 10 set. 2014

BELLEI, Sérgio Luiz Prado. O livro, a literatura e o computador. São Paulo: EDUC; Florianópolis: UFSC, 2002.

BRANCO. Lúcia Castello. O que é escrita feminina. São Paulo: Brasiliense, 1991.

BURNS, Mila. Nasci para sonhar e cantar - Dona Ivone Lara: a mulher no samba. Rio de Janeiro: Record, 2009.

CIXOUS, Hélène. "The Laugh of the Medusa". In.: Signs. Vol. 1, No. 4 (Summer, 1976), p. 875-893. Discponível em: <http://c308femmes.files.wordpress.com/2009/04/cixous-thelaugh-of-the-medusa.pdf > Acesso em: 15 de agosto de 2014. 
COSTA, Claudia de Lima. "O leito de procusto: Gênero, linguagem e as teorias

Femininas”. Cadernos Pagu, vol. 2, 1994, p.141-174.

DALCASTAGNÈ, Regina. "A personagem do romance brasileiro contemporâneo: 1990-2004”. Estudos de Literatura Brasileira Contemporânea, $\mathrm{n}^{\circ}$ 26. Brasília, julho-dezembro de 2005, p. 1371.

"Uma voz ao sol: representação e legitimidade na narrativa brasileira contemporânea". Estudos de Literatura Brasileira Contemporânea, Brasília, Vol. 0, N. 20, jan. 2002. Disponível

〈http://seer.bce.unb.br/index.php/estudos/article/view/2214/1773 > . Acesso em: 31 Agosto 2012.

DEBERT, Guita G. "Problemas Relativos à Utilização da História de Vida e História Oral". In.: CARDOSO, Ruth (Orgs.) A Aventura Antropológica. Teoria e Pesquisa. 4. ed. Rio de Janeiro: Paz e Terra, 2004

DIAS, Karina. "Al encuentro Del amor". In.: GHEZZi, Melissa; SALAZAR, Claudia. Voces para Lilith: Literatura contemporánea de temática lésbica en Sudamérica. Estruendomudo, 2011 2009

Aquele dia junto ao mar. São Paulo: Brejeira Malagueta,

As rosas e a revolução. São Paulo: Edição do autor, 2014

“De repente é amor". In.: Xana In Box. Disponível em < http://glsplanet.terra.com.br/cgi-

bin/xanainbox/xanainbox.cgi?action=view\&id=1742 Acesso em 14 de maio 2014
Diário de uma garota atrevida. São Paulo: Brejeira Malagueta, 2012.

"Júlia e Sara". In.: VIANA, Fabrício (Org.) Orgias literárias da tribo: nossos dia a dia, desejos e sentimentos. São Paulo: Orgástica, 2014, p. 45-55.

"No ritmo do amor". In.: Xana In Box. Disponível em < http://glsplanet.terra.com.br/cgi-

bin/xanainbox/xanainbox.cgi?action=view $\&$ id $=3037$

Acesso em 20 de agos 2014.

FACCHINI, Regina. "Entrecruzando diferencas: mulheres e (homo)sexualidades na cidade de São Paulo". In: BENÍTEZ, María Elvira Díaz; FIGARI, Carlos Eduardo. Prazeres dissidentes. Rio de Janeiro: CEPESC; Garamond, 2009.

FACCO, Lúcia. As heroínas saem do armário: Literatura lésbica contemporânea. São Paulo: Summus, 2003.

; LIMA, Maria Isabel de Castro. "Protagonistas lésbicas: a escrita de Cassandra Rios sob a censura dos anos de chumbo". Labrys, estudos feministas, études féministes. Florianópolis, n. 6, agos-dez, 2004. Disponível em http://www.tanianavarroswain.com.br/labrys/labrys6/lesb/bau.htm $>$ Acesso em 12 jul 2014.

FERREIRA, Débora. Pilares Narrativos: a construção do eu na prosa contemporânea de oito romancistas brasileiras. Florianópolis: Mulheres, 2004.

GOFFMAN, Erving. A representação do eu na vida cotidiana. Petrópolis: Vozes, 2007.

Estigma: Notas sobre a Manipulação da Identidade Deteriorada. 4. ed. Rio de Janeiro: LTC, 1988.

HEILBORN, Maria Luiza. "Ser ou Estar Homossexual: dilemas de construção da identidade social". In: PARKER, Richard; 
BARBOSA, Regina. Sexualidades Brasileiras. Rio de Janeiro: RelumeDumará, 1996, p. 136-145.

HOLANDA, Ismênia de Oliveira. (Re)escrita de identidades lésbicas no Brasil Contemporâneo: a experiência da Editora Brejeira Malagueta. 2012. 105 f. Monografia (Graduação em Ciências Sociais). Universidade Federal do Ceará, 2012.

KOSELLECK, Reinhart. "História como conceito mestre moderno". In.: ; ENGELS, Odilo; GÜNTHER, Horst; MEIER, Christian. O conceito de História. São Paulo: Autêntica, 2013.

LAHIRE, Bernard. A cultura dos indivíduos. São Paulo: Artmed, 2006.

LEJEUNE, Phelippe. "Autoficções \& Cia. Peça em cinco atos". In.: NORONHA, Jovita (Org). Ensaios sobre autoficção. Belo Horizonte: Editora UFMG, 2014, p. 21-38.

LINHARES NETO, Guilherme. A cidade (pós)moderna e suas tramas espaciais, temporais e afetivas nas narrativas literárias de Daniel Galera e Daniel Pellizzari. 2009. 112 f. Dissertação (Mestrado em Sociologia). Universidade Federal do Ceará, 2009.

MACHADO, Patrícia. "Escrita feminina". In.: E-dicionário de $\begin{array}{llcl}\text { termos literários. } & \text { Disponível } & \text { em: } \\ \text { http://www.edtl.com.pt/index.php?option=com } & \text { mtree\&task=viewl }\end{array}$ http://www.edtl.com.pt/index.php?option=com mtree\&task=viewl

MORALES, Lúcia Arrais. "Lota de Macedo e Elizabeth Bishop: projetos interrompidos". In: Seminário Internacional Fazendo Gênero 9: Diásporas, Diversidades, Deslocamentos, 2010, Florianópolis - SC. Universidade Federal de Santa Catarina, 2010. v. 1. p. 1-10.

Dossiê Literatura e Memória

Arquivos do CMD, Volume 3 N.2. Ago/Dez 2015
MUNIZ, Celina (Orgs). Fanzines: autoria, subjetividade e invenção de si. Fortaleza: Edições UFC, 2010.

NAVARRO-SWAIN, Tânia. "Feminismo e Lesbianismo: quais os Desafios". Labrys, estudos feministas, Études féministes. Florianópolis, n. 1-2, julho/dezembro 2002. Disponível em < http://www.tanianavarroswain.com.br/labrys/labrys__2/femles.ht $\underline{\mathrm{ml}}>$ Acesso em $12 \mathrm{dez}$ de 2013.

OLIVEIRA, Rosa Meire Carvalho de. Diários Públicos, Mundos Privados: diário íntimo como gênero discursivo e suas transformações na contemporaneidade. Salvador: 2002. Dissertação (Mestrado em Comunicação e Cultura contemporânea), Universidade Federal da Bahia.

PÉRET, Flávia. Imprensa gay no Brasil. São Paulo: Publifolha, 2012.

PIVA, Wagner de Oliveira. "Marketing na web 2.0: A força dos blogs". In.: LAS CASAS, Alexandre (Org). Marketing Interativo - a Utilização de Ferramentas e Mídias Digitais. São Paulo: Saint Paul, 2010.

PORTINARI, Denise. $O$ discurso da homossexualidade feminina. São Paulo: Brasiliense, 1989.

PROGRAMA Mulheres Poderosas. Direção: Silvia Canquerini. Produção: Silvia Canquerini. São Paulo: All TV, 2009. Disponível em: 〈 http://www.youtube.com/watch?v=z4dlESRfG70 > Acesso em: 5 set. 2014.

SANTOS, Rick. "Apresentação crítica e atualizada desta edição". In.: RIOS, Cassandra. Uma mulher diferente. São Paulo: Brasiliense: 2005.

SCHITTINE, Denise. Blog: comunicação e escrita íntima na internet. Rio de Janeiro: Civilização Brasileira, 2004. 


\section{Ismênia de Oliveira Holanda}

\section{Antonio Crístian Saraiva Paiva}

SCHWANTES, Cíntia. "Espelho de Vênus: questões da representação do feminino". In: MUZART, Zahide (Org.). A mulher na literatura, n. 9, Boletim do GT, Anpoll. UFSC,
2000/2002
187-193.
Disponível
em:

<http://www.amulhernaliteratura.ufsc.br/artigo_cintia.htm >

Acesso em: 03 maio de 2014.

SEVCENKO, Nicolau. Literatura como Missão: Tensões sociais e criação cultural na Primeira República. São Paulo: Brasiliense, 1983.

SOARES, Eliane Veras. "Embora lidando com literatura, você está fazendo sociologia". Civitas. Porto Alegre v. 14 n. 1 p. 81-92 jan.-abr. 2014. Disponível em:

http://revistaseletronicas.pucrs.br/ojs/index.php/civitas/article/view 16183/10960> Acesso em: 03 jul 2014.

SOUSA FILHO, Alípio. "Por uma teoria construcionista crítica" Bagoas. Natal, v. 1, n.1, p. 27-59, jul.-dez., 2007.

SPIVAK, Gayatri Chakravorty. Pode o Subalterno Falar? Belo Horizonte: Editora UFMG, 2010.

TODOROV, Tzvetan. A Literatura em Perigo. Rio de Janeiro: DIFEL, 2009. 